\section{THE FORESTRY COMMISSION}

THE FIRST TWENTY-FIVE YEARS

\author{
By Prof. E. P. STEBBING \\ University of Edinburgh
}

$\triangle \mathrm{S}$ a result of the restrictions on imports and the heavy fellings made in the woods in Great Britain during the War of 1914-18, a Forestry SubCommittee was set up to consider the question for the country as a whole, and its report, the Acland. Report, was accepted by the Minister of Reconstruction and the Cabinet as a basis upon which to frame a Forestry Bill. This Bill was passed in 1919.

The idea underlying the framing of the Bill was the necessity of making provision, against a possible future war, for a three years supply of timber and pit wood in the country. The estimated area to furnish this amount was laid down as 1,770,000 acres. This area was to be planted in a period of eighty years at a total cost of $£ 15,000,000$. During the first ten years, for which the Bill provided, an area of 250,000 acres was to be planted at an estimated cost of $£ 2,872,500$.

The chief work, therefore, of this new State Department was to bring into being a State ownership of forest land and to afforest all suitable parts of these areas; to create, in fact, national forests, a type of ownership of woods which had never previously existed in Britain. For the so-called State forests, the Dean, New Forest, and so forth, were originally, and had come down to us solely as, the personal property of the Crown. This pioneer work of acquiring land, draining, clearing, fencing and raising the plants required in nurseries and having the requisite number ready each year for the estimated areas to be planted up was by no means so easy as had perhaps been anticipated by some of the most ardent adherents of the new departure. Further, the recruitment of the indispensable trained staff proved another difficulty. Under the Forestry Bill the Commission was to receive annual grants to cover its expenditure. In forestry, a type of work necessitating the longest views, since trees do not grow to maturity in the brief space of agricultural crops, a departmental budget based on stability is indispensable. The financial crises which supervened between 1920 and 1931 had their automatic effects on checking and upsetting the annual planting plans so rigidly laid down in the Acland Report, one of its chief failings, and consequently the activities of the new department. In this connexion and owing to the inexperience of the staff, unnecessary waste was possibly incurred at these set-backs. Large numbers of plants were actually burnt in the great nurseries owing to the cutting down of the yearly planting programme; whereas there is no doubt that they could, with considerable advantage, if only in the interests of the taxpayer, have been offered at the cost of carriage to private owners of woods, as is so commonly done in Europe and, in fact, is at the present time being done in certain parts of the British Empire overseas.

In this connexion there was another serious drawback to the Acland Report, to which the Commission adhered so rigidly. The report was based almost solely on the annual planting of conifers. The valuable British broad-leaved species or hardwoods were almost entirely neglected. In fact, in parts of
Britain where poorly managed areas of coppice with standards were purchased with the estate acquired by the Commission, such was the conifer obsession that these areas after being cleared were planted with conifers; this often resulted in a heavy cleaning expenditure for a number of years to prevent the resultant coppice shoots - the natural tree flora of the locality-from smothering and killing the expensively raised and planted conifers.

It will be readily admitted that the new department had to show results, or it would have risked suppression at the hands of a lukewarm Government, House of Commons and public; and conifers ave easier to raise and plant and grow more quickly than hardwoods. Moreover, the bulk of the land acquired by the Forestry Commission was conifer land.

The acquisition of the necessary land did not prove so easy. For one thing, the agricultural parts of an estate together with buildings and so forth had to be acquired; since a depreciation in values would result if only a specified portion of an estate were sold.

In the past twenty-five years the Commission has acquired approximately $1 \frac{1}{4}$ million acres, of which half a million acres has been afforested and a quarter of a million acres remains to be planted. The rest of the land is either unproductive, above the present possible plantable elevation, and mountain tops, or land which is agricultural in its broadest sense and therefore does not fall within the province of the forester. These land areas now belonging to the State, that is, the public, are spread over 263 forests, of which 102 are in England, 39 in Wales and 122 in Scotland. It was foreseen that in these at present out-of-the-way-regions it would be necessary to make provision for accommodation for permanent forest workers. A programme was therefore prepared for the building of forest holdings, that is, houses each with an acre or two of land to produce vegetables and so forth; 1,500 of these holdings have been established during the period.

In England and Wales an area of 625,505 acres of land has been acquired, of which 464,178 acres is plantable land, the rest being described as agricultural holdings, nurseries, unplantable, etc. The areas planted were 276,898 acres of unafforested land and 49,102 acres of acquired woodland (the New Forest, Forest of Dean, etc., made over to the management of the Commission). The chief species used in the re-afforestation work and in planting in the acquired woodlands were Scots and Corsican pine, European and Japanese larch, Norway and Sitka spruce, Douglas fir (very popular in the early years of the Commission), oak and beech. In Scotland the total area acquired has amounted to 627,000 acres, of which 316,000 acres is plantable. The area planted has amounted to 163,000 acres, the species used being Norway and Sitka spruce, about 53 per cent; Scots and Corsican pines, about 26 per cent; European and Japanese larches, about 11 per cent; others, 10 per cent.

On the subject of private forestry, the Commission states that grants given for planting in private woodlands have been made in respect of 145,000 acres, the grant being $£ 2-£ 4$ per acre. Land owners, while gladly acknowledging this assistance, complained that since practical assistance by the Commission was not available, the planting-rate on estate woodlands was not much more than 6,000 acres a year, as compared with nearly double in the early years of the present century; although after 
the heavy war fellings during 1914-18 the plantingrate should have been greatly accelerated. In 1914 some 97 per cent of the woods in Great Britain, amounting to $2 \frac{1}{2}$ million acres, were privately owned. The Commissioners claim, nevertheless, that advice an many aspects of forestry has been given to private awners. But it must be admitted that the private owners had a strong case when they maintained, first, that the new and very young State forest staff had a full-time job, increasing with the passing years and that little time was therefore available for advice to the private owner. More than this was, however, involved; the training and experience of the staff, with no long tradition and no precedents behind them, were not always adequate to enable them to advise in the management of estate woodlands, especially the smaller ones, which presented a whole set of quite different and often very complex problems.

An interesting side-line of the work of the Commission, but a natural development, as it turns out, is the creation of three national parks on the Stateowned forest land; and two more are to follow. The controversies which have taken place over the question of the afforestation of beauty spots were probably almost inevitable in a country such as Britain, with a population which knew nothing about forestry or its objectives and had lost all forest sense. That the young department may have blundered in some cases is scarcely to be wondered at. But the ignorance of the public on the subject was equally apparent.

Towards the end of the period here dealt with, the Commissioners have prepared two White Papers on post-war forestry. The first of these has had a first reading in the House of Commons.

The present Commissioners were appointed by the King, and their average length of service is now ten years. The first chairman and the man who may be said to have made the Commission was the late Lord Lovat, 1919-27 ; followed by Lord Clinton, 1927-29 ; Sir John Stirling Maxwell, 1929-32; and then Sir Roy L. Robinson, 1932 to date. Mr. Robinson was the technical commissioner to Lord Lovat and remained in the Commission in this capacity until his appointment as chairman. In the first few years, the Commission consisted chiefly of landed proprietors-to this reason perhaps may be attributed the failure to start replanting all the cut-over areas of 1914-18, since they might have been accused of helping themselves. On the other hand, it is conceded that it was due to Lord Lovat as chairman that the Commission survived the financial crises which supervened so quickly after its birth. Latterly, the Commission has had a far greater political and House of Commons flavour in its composition.

A point often raised during the past twenty-five years was the irresponsibility of Ministers and the Cabinet for the progress of forestry in Great Britain. The Forestry Commission was represented by a Commissioner, a member of the House of Commons, who acted as its spokesman. Many considered that this was far from effective; that it placed the afforestation programme of the country, a purely public matter, in constant jeopardy; that, in fact, either the business was sufficiently important to deserve the attention of, and responsibility for, a Minister of State; or the Government should give its reason for leaving the matter in the hands of a more or less autocratic authority control led solely by the Treasury. This may be said to have been the practice at the close of the twenty-five years work. In the House of Commons on February 15 it was announced that the Minister for Agriculture and the Secretary of State for Scotland will in future be jointly responsible for forestry, the Forestry Com. mission being retained as an advisory body with executive functions (see p. 311).

One of the present troubles the staff of the Forestry Commission have had to deal with has been fire damage, always a serious danger with large areas of young conifers. Considerable research work into certain problems in connexion with little-known aspects of the work facing them was undertaken in the early years; for example, investigations into seed qualities, and the best regions to obtain the seed from, since so many of the species being used in the new work were exotics; nursery investigations on methods of sowing, soils, rate of growth and so forth, manuring, diseases in the nursery, both fungal and insect attacks, etc., including climatic factors, brought forth excellent results in some cases; as also the studies made of the soil flora in different regions, and growth statistics. More spectacular and easier to understand were the experiments carried out with the object of learning how to plant areas of peat land often of some depth, of which a not inconsiderable proportion of the land acquired by the Commission consisted. Sufficient here to say that great success was attained in some regions by the employment of tractor ploughing. The great increase in mechanization in connexion with farm implements of all types enabled the Commission to devise, and the makers to construct, a tractor plough of such power that areas of deep peat, hitherto beyond the ability of man to cultivate in any way, are now turned up into deep furrows and ridges, enabling drainage to be given to the area while the young trees are planted on the ridges. Continually increasing areas of such lands are being afforested, and it is a sight well worth visiting, whether from a scientific or popular point of view.

Other experiences likely to be of considerable interest to the scientific man are the investigations which have had to be taken up at short notice in connexion with pests. In the early years, great hopes were placed on the Douglas fir; but a Chermes appeared on it and threatened young plantations wholesale. The Hylobius weevil was a well-known pest, but although in Prussia chiefly confined to Scots pine, the extended work of the Commission showed that the weevil would attack several of the exotic coniferous species being used. The interest of this work lies in what is becoming a recognized factor in planting work, whether agricultural or forestry, that a large and sudden extension on a countryside will invariably be accompanied by an increase in local pests, and not uncommonly the appearance of new ones.

Looking back over the past twenty-five years, it may be said that the Forestry Commission and its officers are to be congratulated on the work which has been accomplished in spite of often difficult obstacles. The public now participate as owners in a forestry estate which with adequate support, both financial and otherwise, will form a great asset to Great Britain; always provided that the growth of the hardwoods in their respective regions is not neglected, for some of them produce the finest timber of the temperate zone, while their beauty has made English scenery as enchanting as any the world can show. 